\title{
Sacred Spaces in Medieval and Early Modern Shintō Rituals
}

\author{
YONEZAWA Takanori
}

Translated by Kristopher REEveS

$\mathrm{I}$

$\mathrm{t}$ is customary in Shintō shrines to delineate sacred spaces and other boundaries by means of stylized gates (torii 鳥居) and fences (miqugaki 瑞垣). These liminal markers of sacred space were in use from before the early modern period. I would like here to investigate the various uses and significance of these particular markers in early modern Shintō rituals, especially insofar as they relate to a certain lineage of syncretic Shintō typically referred to as Shinbutsu shūgō shintō 神仏習合神道—hereafter referred to simply as Shinbutsu Shintō-in which Shintoistic deities (shin 神) are understood to be temporary manifestations of Buddhist divinities (butsu 仏). In particular, I will focus on the ordination rite called kanjo 灌頂, which involves the pouring of water onto an acolyte's head, of a single sub-branch of this lineage known as Miwa Shintō (Miwaryū shintō 三輪流 神道). I hope to show how torii gates and mizugaki fences were used during this ritual as a means of creating a sacred space. Miwa Shintō was developed out of Ömiwa Shrine 大神神社, located in Sakurai City 桜井市, Nara. According to the origin account of this sect, an account made famous during the middle of the early modern period, Miwa Shintō was founded at the moment when a Buddhist monk by the name of Keien 慶円 (1140-1223), also known as Miwa shōnin 三輪 上人, or the Sage of Miwa, and Miwa myōjin 三輪明神, the god of Mt. Miwa, exchanged vows and esoteric teachings with one another. Fortunately for us, Miwa Shintō has preserved numerous documents relating to ritual conventions, for which reason we know a great deal about the contemporary structure of this sect's sacred spaces. ${ }^{1}$

\footnotetext{
${ }^{1}$ For the remainder of this paper, I have made reference primarily to the following sources: “Miwaryū kanjō shiki, kenyo" 三輪流灌頂私記 憲誉, in Ōmiwa jinja shiryō henshū iinkai 大神神社 史料編修委員会, ed., Ómiwa jinja shiryō 大神神社史料, volume 5: Miwaryū shintō hen: ken 三輪流 神道篇 乾. Tokyo: Yoshikawa Kōbunkan, 1978, pp. 222-234; "Miwaryū shintō kanjō shitaku" 三輪流神道灌頂支度, in Ibid, volume 6: Miwaryū shintō hen: kon 三輪流神道篇 坤. Tokyo: Yoshikawa Kōbunkan, 1979, pp.524-528.
} 


\section{The Shintō Kanjō Rite and the Sacred Hall}

The purpose of the Shintō kanjō rite is to transmit central doctrinal teachings (shintōsetsu 神道説) of the sect to the one ordained. Based on a similar ritual practiced in esoteric Buddhism, this rite consists of ceremoniously dropping a single flowers (tōke 投華) upon the daidan 大壇, or Greater Platform, and passing on various secret teachings and other central transmissions of the sect upon the shödan 小壇, or Lesser Platform. This rite takes place within a building known as a dōjo 道場, or Sacred Hall, the inner divisions of which are delineated by means of curtains and folding screens. The various partitions of this sort that separate the inside of the Sacred Hall from the outside environment serve also to create a sacred religious space in which statues of Shintoistic deities and Buddhist divinities may be ceremoniously placed.

\section{Delineating Sacred Spaces within the Sacred Hall}

The Sacred Hall (Figure 1), when used for conducting the kanjo rites, is separated into a number of sacred spaces by means of the following structures:

1. Shimenawa 注連縄 (sacred ropes): A number of sacred ropes are used to delineate sacred spaces: First, the entire hall itself is ritualistically separated from the outside world by means of a long sacred rope running around the hall's outermost perimeter. Second, the outer chamber (gein 外陣), where the ordinands and the choir (sanju 讃衆) are seated before the ceremony is likewise delineated. Third, the inner chamber (naijin 内陣), the central location of the ceremony where the platforms are erected, is similarly circumscribed. Here we see the original significance of shimenawa, namely, to circumscribe and maintain the ritual purity of sacred spaces. It should be noted here that as one moves from the outer to the inner sacred spaces, in the order just described, the number of paper streamers (shide 紙垂) and sakaki 榊 (Cleyera japonica) branches attached to each respective sacred rope increases, thereby representing a corresponding increase in ritual purity.

Another sub-branch of Shinbutsu Shintō, established first by the Edo-period Shingon monk Jiun Onkō 慈雲飲光 (1718-1805), and known as Unden Shintō 雲伝神道, has transmitted to us records of the structure of its ritual space used for conducting the kanjō rite. According to these records, Unden Shintō set up liminal markers, known as Ama no ukihashi 天の浮橋, the Heavenly Floating Bridge, and Ama no yachimata 天の八忂, the Heavenly Eight-Branched Road, to separate the sacred space of the ritual from the outside mundane world. ${ }^{2}$ Both of these structures were modelled after mythical topoi supposed to have been situated somewhere between heaven and earth, and, as such, were placed just

\footnotetext{
2 “Shintō kanjō seiki” 神道灌頂清軌, in Hase Hōshū 長谷宝秀, ed., Jiun Sonja žnsho 慈雲尊者 全書, volume 10, Kōkiji 高貴寺, 1924, pp. 881-917.
} 
outside the Sacred Hall as a means of signifying that the space within the hall had thereby been transformed into a divine world.

2. Torii (gates) and Noren 暖篻 (curtains): The walkway leading up to the Sacred Hall contains a total of three torii gates. According to the teachings of Shinbutsu Shintō, those who pass under these gates are required, at each torii, to pay their respects to the Buddhas and intone a secret poem intended to purify the individual after the fashion of traditional Shintoistic rites. The entrance of the Sacred Hall is covered with a curtain, upon which is depicted an image of the sun and the moon, along with the following passage: "The world of demons and the world of Buddhas_-both of these are embraced by Dainichi" (makai bukkai kore mina Dainichi 魔界仏界皆是大日), where Dainichi is none other than Mahāvairocana, the Great Sun Buddha (Dainichi nyorai 大日如来). This curtain simultaneously conceals the sacred space lying beyond and signifies its sacrality to those about to enter.

3. Kaki 垣 (fences): The daidan, or Greater Platform, the central locus of the kanjo rite is surrounded by a fence, the stakes of which sport tips that are tapered to resemble mountain peaks. There is, furthermore, a torii gate marking the place where participants are to insert their hands through the fence in order to perform the ceremonial dropping of a flower, thereby giving the impression of a miniature replica of the outer surroundings of the shrine itself. The upper portion of the platform contains a shelf on which is displayed Buddhist scriptures, illustrated wooden plaques (ema 絵馬), gilt engravings of floral patterns (keman 華鬘), various decorative banners, along with a canopy (tengai 天蓋) to which is attached a mirror. These items are meant to signify the amalgamation of Shintoistic deities and Buddhist divinites.

\section{Conclusion: Special Characteristics of the Sacred Hall for Shintō Kanjō Rites}

The use of shimenawa and toriz-both of which are strongly associated with Shintoistic and not Buddhist practices — as markers of sacred space in Shinbutsu Shintō rituals indicates that, while creating a purified space for ritual activity, practitioners also sought to emphasize the Shintoistic aspect of the syncretic faith. The sort of sacred space created for Shintō kanjō rites is characterized by set of concentric layers of sacred spaces, each marked off by a shimenawa, and each for sacred than the previous. The same golds true for the series of three torii gates encountered along the walkway towards the Sacred Hall, each gate representing a greater degree of purification. Naturally, the Greater Platform, located as it is at the center of the Hall, signifies the greatest possible degree of ritual purification. This overall structure resembles that of traditional (non-syncretic) Shintō shrines. While Shinbutsu Shintō preached syncretic doctrines that included the amalgamation of Buddhist divinities, the sacred spaces created within 
their halls, spaces where the Shintō deities were believed to appear, were characteristically Shintoistic in their structure, as well as in their consistent appeal to ritual purity. That is to say, while the Shintō deities are not overtly represented, their presence was certainly felt in virtue of the characteristically Shintoistic structure of sacred spaces within their Sacred Halls. In this way, sacred spaces associated with Shintō rituals signified not only a fundamental separation from the mundane world, but served simultaneously as a means of drawing attention to the existence of Shintō deities.

\section{References}

Gangōji bunkazai kenkyūjo 元興寺文化財研究所, ed., Shintō kanjō: wasurerareta shinbutsu shügō no sekai 神道潅頂—忘れられた神仏習合の世界. Nara: Gangōji bunkazai kenkyūjo, 1999.

Ōmiwa jinja shiryō henshū iinkai 大神神社史料編修委員会, ed., Miwaryū shintō no kenkeyū 三輪流神道の研究. Nara: Ōmiwa jinja shamusho, 1983.

Suzuki Hideyuki 鈴木英之, “Shintō kanjō dōjōzu no fukugen” 神道潅頂道場図 の復原, in Bukkeyō bungaku 仏教文学, 41 (April 2016), pp. 28-37.

Yonezawa Takanori 米澤貴紀, “Miwaryū shintō kanjō no ba no tokushitsu" 三輪流 神道灌頂の場の特質, in Nihon kenchiku gakkai keikakukei ronbunshü 日本建築 学会計画系論文集, 78: 687 (May 2013), pp. 1381-1388.

Yonezawa Takanori 米澤貴紀, “Shinbutsu shūgō girei no ba ni okeru kekkai ni tsuite”神仏習合儀礼の場に扮ける結界について, in Nakagawa Takeshi sensei tainin kinen ronbunshū kankō iikai 中川武先生退任記念論文集刊行委員会, ed., Sekai kenchikushi ronshü: Nibon, Higashi Ajia hen 世界建築史論集 日本 ·東 アジア篇. Tokyo: Chūō Kōron Bijutsu Shuppan, 2015, pp. 105-114. 


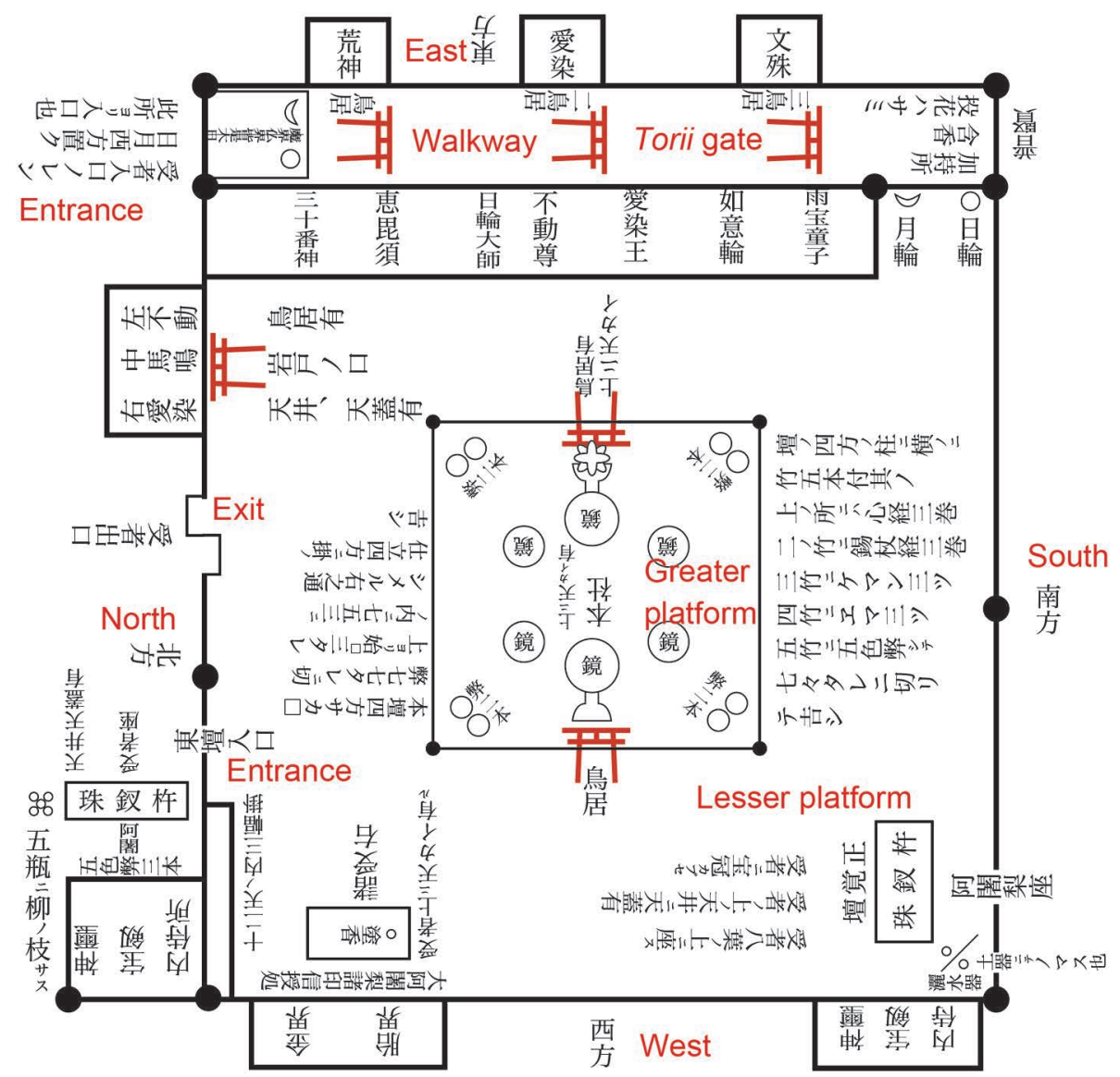

Figure 1. Plan of the Sacred Hall (dōjo 道場). Note that this diagram is oriented with east at the top. The greater platform (daidan 大壇), here listed as the hondan 本壇, is located in the center of the Sacred Hall, while a number of lesser platforms (shödan 小壇) are located around this. The walkway running along the eastern side of the Sacred Hall has three torii 鳥居 gates, as well as a noren 暖笠 curtain hanging over the entrance. "Miwaryū kanjō shiki" (Reproduction and Transcription by YonezawA Takanori). 
